\title{
The Transcendences of Listening to Music: How Listening to Bob Dylan Moves His Fans
}

\author{
ANDREAS HÄGER \\ Åbo Akademi University
}

\begin{abstract}
The theoretical starting point for my article is the concept of transcendence in the writings of Thomas Luckmann and Alfred Schutz. Schutz describes a continuing flow of transcendences of the immediate lifeworld. Luckmann speaks of three levels of transcendence: the 'little transcendences' of an awareness of time and space, the 'intermediate transcendences' of an awareness of the social dimension, and the 'great transcendences', an awareness of dimensions beyond life and death. I add a distinction, central to music, between cognitive awareness and the emotional dimension. I apply this framework to a discussion among Bob Dylan fans of their experiences in listening to Dylan. The material is derived from a Swedish online discussion forum. Examples of both cognitive and emotional transcendence at all three levels are discussed, with particular focus on references to religious traditions in describing experiences of Dylan's music.
\end{abstract}

Keywords: transcendence, fandom, musical experience, religious metaphors, Thomas Luckmann, Bob Dylan

In this article, I discuss the ways in which a group of music fans describe their listening experience. They are moved by certain musical performances, and try to express these emotions in words. The material of the study consists of a thread in a Swedish Internet discussion forum on the American artist Bob Dylan, called 'Love and theft'. ${ }^{1}$ The participants are diehard Dylan fans; they have attended numerous concerts and own hundreds of unofficial recordings, mainly of concerts, circulated among the fans. The

$1<$ www.loveandtheft.se $>$ accessed 9 June 2011. The name of the forum is derived from a Dylan album. I am myself a passive member of the forum, having written 39 posts over six years (none of them in the discussion thread used here). My own knowledge of the forum, and of Dylan and his music, is a direct reason for choosing this case. Most of the active writers on the forum are male, and I have consequently used the pronoun 'he' in referring to them. I have no data as to the age of the posters, but my observations at Dylan concerts and fan events indicate that most - although not all - participants are middle-aged or older. 
name of the discussion thread (in my own translation from Swedish, as are all quotes from the thread) is 'Great moments/Bob kicks ass'. ${ }^{2}$ The thread consists (as of the time of writing; it is still active) of 392 posts written during 9.1.2004-6.9.2011. The bulk of the discussion consists of fans recommending various unofficial concert recordings, which are numerous; Dylan is constantly touring, and all concerts are recorded by and distributed among the fans. The main purpose of the article is to explore the relationship between music and transcendence. It is not of primary importance to me that the music in question is performed by Bob Dylan, that the material originates from an online source, or that the people who are writing are Dylan fans from Sweden. The material, the online discussion of the Swedish Dylan fans, is used as a convenient example of how forms of transcendence occur while listening to music.

The analysis focuses on how these fan discussions express various levels of transcendence arrived at through listening to music. The theoretical starting point for the analysis is derived from Thomas Luckmann and Alfred Schutz, who have a very broad understanding of transcendence. For Schutz, transcendence is everything that goes beyond the immediate lifeworld, the here-and-now. We are aware that there is a world which we cannot see, as both nature and society transcend us in time and space (Schutz 1962, 329). Schutz also emphasizes that the practicalities of the present always exist, for example through the tools needed to achieve transcendence.

Luckmann $(1987 ; 1990)$ describes three levels of transcendence of the here-and-now: little, intermediate and great transcendences. Little transcendences are the transcendences of nature, of time and space. We are aware that there is more to existence than what immediately meets the eye. Luckmann gives an example: when we see an object from one side, we are aware that there are parts we do not see. It is still possible to see these other parts, for example by turning the object around. Little transcendences by definition involve only a single individual, and are central to individualistic religious expression. ${ }^{3}$

Intermediate transcendences involve the social dimension: we become aware of other individuals whom we can communicate with, experience,

$2<\mathrm{http}$ //loveandtheft.se/smf/index.php?topic=121.0 $>$ accessed 9 June 2011. The Swedish title is 'Stora ögonblick/Bob knäcker'. 'Knäcker' is a slang expression which is difficult to translate; it might also be translated for example as 'is devastating /awesome'.

3 Luckmann $(1990,138)$ sees individualism as a religion: 'Modern religious theme such as "selfrealization", personal autonomy and self-expression have become dominant.' 
touch, or merely know of. Little transcendences have to do with things we can fully apprehend, such as the room behind my back or the streets of Reykjavik. Intermediate transcendences in turn refer to things we can never fully know, such as the consciousness of other individuals. Great transcendences, finally, have to do with things that cannot be known rationally: to dimensions beyond life and death, to the supernatural.

The three levels of transcendence are communicated by different types of representations: in C. S. Peirce's trichotomy, by index, sign and symbol (Luckmann 1987). Little transcendences are indexical, referring to something that can be experienced directly and represented by something that has is physically or causally related to that which is not present - as the front of an object indicates its back, or medical symptoms indicate a disease. Intermediate transcendence is communicated by signs, which in contrast to indexes are arbitrary, with a completely conventional connection between signifier and signified. Finally, symbols are signs referring to something which is not of this world; they are therefore the means of communicating great transcendences. A special type of sign is the metaphor. In the material, the descriptions of fans' experiences of Dylan's music often use metaphors, including sometimes very striking images.

Luckmann is a sociologist of knowledge, and in his discussion of transcendence he focuses on the cognitive awareness of nature, society and God. The emotional dimension is absent or at least merely implicit. ${ }^{4}$ What I am attempting to do here is to make the emotional aspect explicit. I give examples of both cognitive and emotional transcendence that occur while listening to music. In the material, emotions are often described metaphorically.

The three levels of transcendence, and the distinction between the cognitive and emotional aspects, produce a classification of transcendence. The categories arising from this classification are necessarily loose, as may be seen in the discussion below. Materials such as written texts are too rich and too complex to be easily categorized. When the text is an attempt to describe something possibly even more complex, such as the experience of listening to a piece of music, the difficulties multiply. This should be kept in mind with regard to my attempt to apply these categories.

Luckmann and Schutz obviously have a much broader understanding of the concept of transcendence than a more traditional, everyday understanding equating transcendence with trance or ecstasy. The narrower under-

4 Obviously there has been something of an 'emotional turn' in the social sciences, including the sociological study of religion (Riis \& Woodhead 2010), since Luckmann published the works cited here. 
standing of transcendence fits primarily into Luckmann's category of great transcendence, an awareness of the divine, or into some more emotionally intense forms of little and intermediate transcendences.

The title of Luckmann's (1990) classic article speaks of 'shrinking transcendence' and 'expanding religion'. Luckmann discusses transcendence in relation to changes in the place of religion in modern society. The process of functional differentiation of society has led to a privatization of religion, accompanied by a sacralization of the individual. The privatization of religion and the forces of rationalization, particularly disenchantment (Entzäuberung), lead to a shrinking transcendence. In other words, the great transcendences, which the churches have held the monopoly on organizing, have become less important. This in turn, according to Luckmann, has led to an expanding religion, since the little transcendences focusing on the individual and on the intermediate transcendences of social life that are gaining in importance are organized by a greater number of institutions. Rather than a single institution monopolizing religion in the form of great transcendences, we thus have many institutions dealing with religion, mainly in the form of lower-level transcendences.

My primary purpose here is not to go into a discussion of these major topics that are central to Luckmann, although I comment briefly on these issues in the concluding part of the article. I rather attempt to use Luckmann's discussion of transcendence as a tool for exploring how Swedish Dylan fans describe their musical experiences. My main interest lies in what might be seen as descriptions of great transcendences, more precisely the use of references to established religious traditions. I see Luckmann's point when he describes the shrinking of transcendence and the expansion of religion, but I am more interested in the continuing role of the great transcendences traditionally organized by the shrinking churches. The references to religion in this material - and in popular culture in general - live on, as metaphors and even ironically, but as something that can be used to express feelings and experiences for which religious language is a suitable means of expression. Before continuing with this discussion, I take a brief look at how the little and intermediate transcendences of listening to Dylan's music are expressed by the Swedish fans.

\section{Little Transcendences}

Little transcendences are transcendences of space and time. The discussion on the Bob Dylan forum mostly concerns recorded music, which always 
transcends space and time. An awareness of this is constant in the discussion, with references to the date and place of a particular recording: for example 'Birmingham, June 7th 1989'. The music moves the listener in time and space, and this is commented on explicitly by one fan:

Consider that one moment you are able to listen to a few days old recording of 'Mississippi', and the next hour you can choose to listen to - and watch - a miraculous 'To Ramona' from 1995.

With an artist such as Dylan, whose career spans a period of fifty years, the period of a particular recording is central to the listening experience, while the category of space, the actual venue of the concert, is usually secondary. There is also an awareness that listening to a concert is not the same as the immediate experience: 'If only I had been able to experience this on the spot' or, regarding concert DVDs, '[s]ome films almost succeed in catching the experience of seeing Dylan live' - but only almost.

Most of the discussion in the thread relates to recorded music. One fan talks about the memory of attending a Dylan concert:

One of the greatest moments of my life, when it gets started in Göteborg 78 , front row, second concert. Thank you Bob, I'll carry that with me for the rest of my life!

These little transcendences I consider cognitive, a rational awareness of time and space. The last quote, remembering 'one of the greatest moments of my life', obviously also expresses a strong feeling. There are many other expressions of strong emotions that I have grouped in the category of little transcendences, since they focus on the listener him- or herself and are expressed indexically.

These emotions are often expressed in relation to the listener's own body:

I get shivers all down my spine and the hair stands up on the back of my neck. A firestorm!

People describe themselves as 'floored', 'struck senseless' or 'sitting there with a silly grin again'. One fan says that after listening to a Dylan song,

I have to gather the remains of what used to be the body I lived in. 
Another kind of bodily experience, a sense of taste and smell, is evoked by a fan who describes a recording as a 'high class Single Malt in sound format'. It is obvious that most of these expressions are metaphorical - I do not believe that the listeners are literally struck senseless or have their bodies ripped apart. Emotions are also expressed in other metaphors, as in the above quoted 'firestorm'. Other examples of metaphors are discussed below.

\section{Intermediate Transcendence}

The most obvious example of intermediate transcendence expressed by the Swedish fans in relation to listening to Dylan's music involves references to his performance and that of members of his band. For example:

Dylan sings properly and the voice holds up well but this version is the most fantastic of all because of JJ Jackson's eminent guitar playing.

The material studied is a fan discussion, a community listening together, as it were. This is expressed in the discussion through a constant awareness of the other members of the board: 'Haven't you heard it, Leif?' or 'Thanks for your first post, Micke'.

I see the emotional aspect of the level of intermediate transcendence as an awareness of the emotions of others, in the form of sympathy and empathy from the fans. There are many expressions of how the fans perceive Dylan's emotions. Music has always been considered an art form which is particularly eloquent in expressing emotions and effective in producing them. Dylan is a strongly emotional artist, conveying his own feelings and producing feelings in others, as described for example in the extensive critical work by Paul Williams (e.g. 2004).

Some expressions of the fans' perceptions of Dylan's emotions are concrete: 'I'm sure he sings with his eyes closed.' Others again are more metaphorical: 'Bob sounds like he's going to explode', or

Bob and the band sound like a bunch of horny ferrets running around manically up there on stage.

As most of the recordings discussed are from concerts, the audience is often audible, and this is also sometimes commented on: 
The audience goes nuts. There is a guy there just roaring in ecstasy, I don't know if he's having a fountain orgasm or something, but that kid must have had the greatest experience of his life.

As in the preceding example with the 'horny ferrets', this statement describes a perception of strong emotion. In both examples these feelings are described metaphorically, and by means of sexual metaphors.

\section{Great Transcendence}

Thomas Luckmann (1990, 129-30) gives two complementary definitions of great transcendence. On the one hand, a great transcendence is something which 'is definitely not part of the reality in which things can be seen' or felt by other senses; on the other, he speaks of 'the "great" transcendences of life and death'. Here I adopt this twofold understanding, seeing the level of great transcendence partly as an awareness of the supernatural, partly as an awareness of death. The second of these categories, which I call the existential dimension, is here equated with the cognitive, although a cognitive awareness of one's inevitable demise is hardly devoid of emotion.

\section{The 'Existential' Aspect}

I present two quotes in the discussion forum explicitly tying Dylan and his songs to one's own death. The first quote comes in a discussion on versions of Dylan's song 'Mr. Tambourine Man':

'Mr. Tambourine Man' from Sheffield 2000. The only song I have requested for my funeral, actually.

No reason is given as to why this particular track is suitable for a funeral. But this particular version of 'Mr. Tambourine Man' from a concert in the year 2000 - when the same song was performed in concert by Dylan a total of 27 times (Björner 2001) - has moved this person in such a way that he wants to leave it to his loved ones as a final memory of him and make it his guide to the realm of the dead.

Another quote sees the brevity of life from another perspective: 
So many songs, so little time. One should get rid of all broken cars, broken houses, a few hobbies.... and perhaps have time to become a happier person before the film ends. Because you become happier from this stuff. Clearly. And more ...complete... as a human being.

This is a quote from a person who evidently listens to Bob Dylan quite extensively; otherwise he would not be writing in this forum and discussing these various Dylan concert recordings. He still thinks that life is too short for all the Dylan music out there, and that he should listen more to become happier and more 'complete as a human being'. Particularly in the last remark, this Dylan fan gives listening to Dylan's music a crucial, existential role in (his) life.

\section{'Visions'}

Many fans speak of the various visions, both of this world and of others, they experience while listening to Dylan's music. It cannot always be said that these are experiences of great transcendence; they can often be read as descriptions of listening to music in metaphorical terms. It is therefore not always clear that they refer to great transcendences; but especially in those cases where a fan explicitly states that they 'see' things while listening to Dylan's music - even if this may, and probably should, also be taken metaphorically - the descriptions can be seen as visions and therefore as something supernatural by definition.

Music moves the listener 'geographically' or 'historically' in several ways. In the case of recorded music, as already discussed, the listener is moved to the time and place of the recording in question. More relevant in relation to the topic of visions, the content of the music and the lyrics moves the listener to different places. If the lyrics of a song speak of New York, or of medieval England, that is what the listener sees in his or her mind's eye. A musical sound inspired by the musical tradition of a country or region moves one to that particular part of the world. Interpretations and discussions of a song may also influence the associations and visions, as does knowledge of the performer in question. This may be the case particularly among fans with expert knowledge of both artist and music.

One fan imagines, regarding a concert in Vienna, that

the songs become beings on their own, threatening to devour all of Austria this evening. 
This is a form of magical vision, where the songs become animated beings - who apparently happen to be very hungry.

The description of one recording states that

Bob bellows like a deer and the members of his posse are shooting from the hip. This was a time when the Wild West was really wild and gun slingers got what they deserved. ${ }^{5}$

The quotes contain no direct reference to any emotion, but particularly the description of Dylan's sound seems to refer to his emotional state. As in a previous quote, an animal metaphor is used. Like many of the metaphors in the material, these are not easy to understand. The concert described in the last quote took place in London, England in the 1990s; the song referred to is 'Queen Jane Approximately', the lyrics of which describe a queen and her court. The reference to the Wild West is not related to the concert or the song but is a matter of free association by the fan in question. As the word I have translated as 'gun slinger' is the same one used to describe the members of Dylan's band, his 'posse', it is also difficult to understand why this fan wants to punish them - to see that they get what they deserve as he apparently likes the music they perform. In recent years, the period during which the discussion analyzed has taken place, Dylan and his band have often performed in costumes and hats reminiscent of the old West, and similar visual references were evident for example in Dylan's tours in 1975-76. In the song 'Nettie More' from 2006, Dylan sings that he is 'in a cowboy band'. These - albeit vague - references to the Wild West may have been on this fan's mind and led to this association. ${ }^{6}$

One vision comes from an empathic experience of another listener's feelings at a concert, along with the hope the listener in question would turn out to be an ardent Dylan fan:

During 'Blowing in the Wind', my date starts crying heavily. I was absolutely crushed. In that moment, I was convinced we would get married and have approximately fifteen children, all named after different Dylan characters

5 This quote contains several translation difficulties. The Swedish word 'vapendragare', which translates as 'weapon-bearer' and has a dictionary translation as 'partisan', is used twice in the quote. I have first translated it as 'the members of his posse', the second time as 'gun slingers' - which of course is a word with similar content as 'weapon-bearer - to fit the context. The word I have translated as 'bellow' is 'bröla' in the original Swedish.

6 The lyrics to all Dylan songs may be found at the artist's official web page, <www.bobdylan.com/ songs $>$ accessed 30 November 2011. 
[...] It felt so real, I could hear her maternal voice asking things like 'have you changed the diapers on Judas Priest, ${ }^{7}$ darling', and similar affectionate things.

This is a very 'mundane', this-worldly vision of family life, including dirty diapers. It also has an existential dimension: the person sees his future life with partner and family - a vision which, as far as can be seen from the post, was not realized in this way. It was, however, apparently a strong vision, as the fan declares that 'it felt so real'.

Another, more negative and less personal, vision is related to listening to Dylan's song 'Señor (Tales of Yankee Power)':

I keep listening to 'Señor (Tales of Yankee Power)' which doesn't let go. Ouch. It's so heavy. And I had completely different associations today. I saw in front of me, not a Western/hippie dream with acid-inspired psychedelic pictures, but horrid pictures of children, old men and women transported to Auschwitz, naked in the showers, or kneeling waiting for a bullet in the back of the head.

It is clear that this fan is speaking of what he describes as a vision: 'I saw'. This fan seems to have had a regular association with the song, 'the Western/ hippie dream', but this can also be understood as an idea of a prescribed vision coming from this song. In a few concerts in 1978, Dylan described the song 'Señor' as the story of an old man on a train in Mexico (Heylin 2010, 103-4). The song has become associated with trains; it contains one mention of the word train in the lyrics, in the expression 'trainload of fools', which is quoted in the post. This leads this listener to the trains to Auschwitz. Listening to Dylan's song and its lyrics gives this fan a vision of one of the great tragedies of our recent history.

References to popular culture are used as metaphors for comparison. One example is this vision:

I see Frank Booth before me, you know the psychopath in Blue Velvet, played by Dennis Hopper. It sounds both threatening and somewhat desperately beautiful.

The same character from the David Lynch film is also referred to in another post in the same thread. There are also other examples of 'recycled' metaphors, where the fans borrow expressions from each other. On the other

7 This is here a reference to a character in a Dylan song, 'The Ballad of Frankie Lee and Judas Priest', rather than to the English metal band taking its name from the same character. 
hand, the many stark and unexpected images used to describe a listening experience give the impression that the fans are also competing in the art of expressing themselves vividly and imaginatively.

The following is a response to the previous quote on the 'ultimate' version of the song 'Mr. Tambourine Man'.

I guess you mean 'Mr. Tambourine Man' in Sheffield 1966? Yes, it was frantically, incredibly, stunningly good, with a Dylan in trance playing looooong harmonica solos which move the listener beyond time and space. Suddenly it is over and the applause fills the hall. Then you are back in reality again. At least until you press repeat. ${ }^{8}$

This is another kind of vision, not of a concrete place or person, but of other dimensions 'beyond time and space'; somewhere where it is physically impossible to go in the normal, everyday world. And when you find yourself back in the real world, you can revisit this strange dimension simply by listening to the song once again.

A quote referring to an official recording, Volume 7 of the so called 'Bootleg series', ${ }^{9}$ goes: 'BS vol 7 disc 2 . Free fall, no parachute. It's almost supernatural.' I now move on to references to things that are entirely supernatural.

\section{Religious References}

There are quite a few religious references in the discussion thread on Dylan's 'great moments'. In line with what has been said, these are clearly part of the references to great transcendences. They refer to particular religious traditions, mostly Christianity but also others. I view them as tools to describe emotional experiences of the music, in the same manner as the visions and metaphors described above. The fans describe strong feelings and profound experiences, and use as a tool the traditions where such experiences have been 'organized', in Luckmann's term.

Bob Dylan was born to a Jewish family, converting to evangelical Christianity at the end of the 1970s. During 1979-1981 he released three albums

8 The previous quote cited a version of the song from Sheffield 2000. By the formulation 'I guess you mean', this fan is quietly mocking his fellow Dylan admirer, and shows very little respect for the other person's serious comment about his own funeral.

9 These are official releases of material from Dylan's back catalogue, deriving its name from the fact that some of the recordings have circulated unofficially on so called 'bootleg' records. 
which are generally considered 'Christian'; his current views on religion are unknown (see for example Heylin 2003). There is however continuous discussion on the relevance of religion to his work and life. The literature on Dylan and religion includes Christian books focusing on Dylan's Christianity in general (Williams 1985; Marshall 2002; Webb 2006) or specifically on his use of the Bible (Cartwright 1985; Gilmour 2004). Maoz (2005) provides an example of publications viewing Dylan from the perspective of Judaism. Many of these authors emphasize that Dylan has used religious references, for example to the Bible, throughout his work, and not just in the so called Christian albums. There are also critical studies situated outside of a religious context, focusing on certain religious or existential aspects of Dylan (Williams 1980; Ricks 2004).

The material analyzed here is derived from an online discussion forum on Dylan. There are other such sites, along with a number of web pages dedicated to issues relating to Dylan and religion. The blog 'Dylan Devotional' calls itself a 'resource blog for spreading the gospel of Bob Dylan worship music'. A website called 'A lily among thorns' is dedicated to 'exploring Bob Dylan's Christianity', and presents analyses of songs, interviews, and transcripts of stage speeches from the gospel period concerts. There is also a fan site - apparently intended as a joke - devoted to a religious following of Dylan, including a religious calendar and a list of the saints of 'bobism' (Church of Bob). Overall, there is considerable interest, among both fans and critics, in Dylan's relation to religion. ${ }^{10} \mathrm{How}$ this affects the way the fans on the Swedish forum discuss the music is a different question again.

The following quote is from a fan who is not certain what religious figure or tradition is most adequate to describe the music he has been listening to:

Suddenly I stop and let go of everything at hand. I settle down on the couch and reach for the remote control, turn up the volume and press repeat. So unbelievably good. What a groove, what a song, what a voice. Can it be the devil that enters into him? God? Or just the spirit of rock'n'roll?

Whatever the answer, it seems clear to this poster that there must be a supernatural explanation of Dylan's performance in the recording in question. This is an example of how religion is used to express a positive experience, in this case of a musical recording. It is also an example of how practical aspects

10 For a longer discussion of the discourses on Dylan and religion, see Häger 2009. 
make themselves felt, as shown by the references to the remote control and the volume. Similar examples include the reference to the repeat function in one of the above quotes, and the fan quoted below, who speaks of his iPod.

The next example is a comment on a harmonica solo:

The harmonica with a capital H. A euphoric, crazy one, moving on to a ghostlike, dreamy howling, that enters into your marrow and all you can think is JESUS IN HEAVEN. [Capitalization in original.]

The last words are used because no other words seem to be available to express how impressive the harmonica solo is to this listener. Even if the expression 'Jesus in heaven' can be seen as an expletive, it is a clear reference to a particular religious tradition - the one historically dominant in Nordic society - and to a central religious figure.

The next quote is from a fan who has put his iPod on shuffle:

The first eight songs gave me direct access to the heavenly spheres and to the front seat. Then came the ninth song [...] and I passed the heavenly spheres damned fast, continued upward, on stage: 'Every grain of sand' from Globen 1998. Once again, in a league of its own, a completely different dimension.

The purpose of using shuffle mode is not to know what song comes next, thus gaining the benefit of surprise. This listener apparently had a series of pleasant surprises. It is clear from the preceding passage in the same post that there was other music on the iPod besides Dylan, but it is not clear whether any of the first eight songs were his. As in the previous quote there is a reference to heaven, but not as clearly to Christianity. Heaven, like the spheres beyond and a 'completely different dimension' - whatever these may be - are used as metaphors for a strong experience while listening to music. The strongest experience comes in listening to a song included on one of the three records regarded as Dylan's Christian output. This may perhaps be a reason why this fan has chosen a religious metaphor; on the other hand, there is no general connection in this fan discussion between the use of religious references and music from Dylan's Christian period. Dylan released a number of explicitly Christian albums, and his relationship with religion has been a recurring topic in discussions of Dylan during most of his career. In the case of the present material, however, it is not obvious that the listening experiences described by the fans have been influenced by this discussion. 
The following quote on religion, from a discussion of Dylan's great moments, brings up the relevance of religion in relation to Dylan's Christian music:

Drammen Norway 1981, excellent throughout. The voice, the conviction, the heat. It's a pity one isn't religious!

In 1981 Dylan was touring with new songs from his third so-called 'Christian' album; it is the last tour where the Christian material was extensively performed. The quote is a comment on how Dylan's own religiosity influenced his performance positively during this period. The last sentence is an observation by this fan that he would probably appreciate the music even more if he shared Dylan's religious convictions, which he therefore regrets that he does not.

The statement 'My favorite record forever amen, "Highway 61 Revisited"' is not a reference to any mythological place or person, but to a religious liturgical formula. Again religion, in this case religious language, is used as a means of reinforcing one's opinion. Here, religion used in a statement that is not as strongly emotional as most other examples. A Judeo-Christian reference of another kind is the assurance that a recording 'will scare S-n out of you [abbreviation in original]'. This is clearly a positive evaluation of the music in question, and for example in the Christian tradition it is of course also a positive thing if Satan departs from you. To describe a great version of a song, one fan claims that 'a miracle happens in front of our eyes. Or, our ears...'. This is not a reference to any particular religious tradition, but clearly to something supernatural. Another quote refers to a different religious 'tradition', more specifically to religion in popular culture: 'the force is with him, so to speak'. This reference to Star Wars/Jediism is used to describe a Dylan in good shape on a particular evening.

\section{Concluding Discussion}

The topic of music and transcendence gives rise to certain immediate associations, for example to the Sufi musicians discussed in an insightful article elsewhere in this volume. One idea behind this article was to approach the topic from a different perspective, looking at 'transcendence' as more than 'trance'. Alfred Schutz and Thomas Luckmann argue that everyday life is a continuous flow of transcendences. We are constantly aware of the existence of a world we cannot see, either because it is too far away in space or 
time, because it exists within the minds of other individuals, or because it is part of some invisible supernatural dimension.

I have attempted to apply this discussion of transcendence to the experience of listening to music; as such experiences are described in an online discussion among Swedish fans of Bob Dylan. Listening to music involves several aspects of transcendence. Listening to recorded music, which for the most part is the case among the fans in the material, and which of course accounts for most music listening today, always transcends time and space. Intermediate transcendence takes place when we listen to someone else performing music. We are aware of the musicians; we react to them and to the emotions they convey through their music. We are also aware of those who are listening with us. These aspects are present in the studied material.

A central argument by Luckmann (1990) is that transcendence is 'shrinking': we are less focused on God and the supernatural, and more on ourselves and our fellow human beings. In the material analyzed here, there are nevertheless a number of references to what I interpret as great transcendences. Firstly, there are a few examples of (in Luckmann's words) 'great transcendences of life and death'; what I have called the 'existential' aspect of great transcendence. The music evokes thoughts of life and death, and of the brevity of one's own life. Secondly, there are a number of examples of what I have called 'visions', where the fans describe what they see before them while listening to a Dylan song. Thirdly, there are references to religious traditions, mainly Christianity.

I have tried to divide the descriptions of transcendence into 'cognitive' awareness and 'emotional' reaction. Cognitive awareness is most often expressed by a straightforward statement of fact, such as the date and place of a concert or the name of a musician. Emotions are expressed in metaphors: comparing Dylan to an animal or describing one's own musical experience as bodily disintegration. Descriptions of listening to music as a religious experience, such as a trip to heaven and beyond, are not necessarily meant to be taken literally. It is rather the case that religious language describing an experience of great transcendence is here used to describe a particular Dylan recording and the experience of listening to it. Particularly with regard to religious language, I see its use not merely as metaphorical but at times also as ironic. ${ }^{11}$ It is also important to note that religion, for example Christianity, is not the only way to express the experience of listening to

11 This can be contrasted with the apparently very serious religious views of Grateful Dead fans interviewed by Carr (1999). 
Dylan's music - fans also refer to the Wild West, to David Lynch or to a bodily experience; but religion is part of this repertoire of expression.

The people whose discussion I am analyzing are fans of Bob Dylan. The fact that they like Dylan's music forms a major part of their life and their identity. There are members of the forum who have attended more than one hundred concerts; they follow Dylan's shows via fan recordings and discuss Dylan online. Fandom is a phenomenon connected with various forms of popular culture, from sports to Star Trek, and not least with popular music. One particularly ardent group of fans who also have received some academic attention are the Deadheads, fans of the American psychedelic rock group Grateful Dead (Carr 1999; Sylvan 2002). For a study of Dylan fans, see Botvar (2011).

The material discussed in this article is derived from an online fan forum. The function of such a forum is to allow one to keep in touch with likeminded people in order to exchange information and experiences in relation to the shared object of interest, in this case Bob Dylan and his music. A fan forum is also an arena for displaying one's own fandom and to be confirmed in one's identity as a real fan. This is evident in a discussion such as the one studied here, where fans tell each other about great Dylan recordings they have found and enjoyed. They exaggerate their own feelings and their own experience in front of other fans. This serves to show that the recording in question is something extraordinary; they have thus made a great discovery and are knowledgeable fans. It also serves to promote their status as a fan by showing how strongly they react to Dylan and therefore how much he means to them. This I believe is particularly true regarding the religious language. For people who themselves not necessarily are religious, to refer to religion is in a sense to go out on a limb, perhaps risking seeming weird or even pious, in order to express one's love for Dylan - who himself is weird and perhaps even pious. The fans may be ironical when it comes to Christianity, but they are very serious when it comes to Dylan, and want to demonstrate this emphatically.

The discussion of Dylan's ' great moments' can in Bourdieu's (1986) terms be seen as a field for distinction, where it is not enough to say that one likes 'Mr. Tambourine Man'; one has to be able to distinguish among hundreds of versions of the song in question. Powers of distinction are also important for reaching the levels of great transcendence. Just as a follower of Brazilian Candomblé has to be familiar with the music and the drum rhythms in order to be able to reach trance (Rouget 1985, 98), a Dylan fan has to know Dylan's music and be able to distinguish between different versions of Dylan and 
of his songs to fully appreciate them and for example be moved 'beyond time and space' by a harmonica solo.

Fans are able to make fine distinctions in the world of Dylan because of their extensive knowledge of the artist and his music. The fan discussion on Dylan's music becomes a system that refers only to itself. Dylan is compared to Dylan and is measured by the ears and moods of the fans. There is not necessarily anything specific about Dylan or his music which produces a particular form of experience. There are many other artists whose fans have powerful emotional experiences in reaction to the music; in fact, particularly in the context of a live concert, the Dylan fans are much less overtly 'ecstatic' than many pop fans.

Thomas Luckmann (1990) discusses the great transcendences as the realm of the churches. However, with the detraditionalization of religion which is an aspect of the functional differentiation of society and a parallel process to the privatization of religion, taken as a starting point by Luckmann (1990) - the churches no longer can be said to hold a monopoly on the great transcendences. The churches do not have monopoly on or control over Christianity or the use of religious language. It is possible that religion is expanding in the sense that the great transcendences are increasingly organized outside the churches. The privatization and detraditionalization of religion also make it possible for individuals, such as the Dylan fans on the discussion forum discussed here, to pick and mix references and metaphors as they choose, referring freely both to Christianity and for example to American films in describing their listening experiences.

Luckmann is best known among scholars of religion for his very broad definition of religion, which also informs those of his writings which are used here. From such a perspective, it is self-evident that the group of Dylan fans whose discussion I have analyzed in this article not only 'can be seen' as a religious group, but in fact are one. The little and intermediate transcendences present in the music experience are expressions of this religion. In particular the strong feelings described and the creation of a community around something highly valued are examples of this. As Cavicchi (1998) puts it in his ethnography of Bruce Springsteen fans (among whom he includes himself), 'my fandom feels to me far more like religion than politics' (Cavicchi 1998, 8). Comparisons of fandom to religion are frequent in the literature, for example in studies of Star Trek (Porter 1999; Jindra 2000). When it comes to music, the most obvious and publicized examples concern the following of dead artists such as Elvis, whose death gave him a significant religious following (Strausbaugh 1985). In Luckmann's terms, 
the Swedish Dylan fan forum, and the whole of Dylan fandom, can be seen as organizers of transcendence.

The fan forum fits many functional definitions of religion, and as noted above also contains references to substantive religious elements. Substantive elements borrowed from religious traditions can be used to draw attention to and highlight religious functions (the provision of identity and community) in a context outside any narrowly defined institutional religion. References to established religion can be used as a signal that something special is taking place. Making reference to a sphere that one knows (or guesses) has been central to the provision of meaning and belonging, i.e. religion, and applying it in a new sphere, such as popular culture, highlights the fact that it is this new sphere that now performs these functions. ${ }^{12}$ Dylan fans feel that the artist they admire is important to them and that he unites them as a community; one way to express this is to borrow language from established religion. While the fans may be ironical with regard to religion, they are aware that it is taken very seriously by many - including perhaps Dylan himself.

Luckmann $(1987,24)$ writes that

socially constructed transcendent realities influence ('determine') the concrete forms of human experience of transcendence, even though such social constructions are the result of reconstructions of 'original', archetypical human experiences of transcendence.

The 'socially constructed transcendent realities' are the established religious traditions. Luckmann sees these as arising from primary transcendent experiences - in a way similar to what is often described within the traditions themselves. The first part of the quote emphasizes that the traditions influence subsequent experiences of transcendence by providing tools and a language for these experiences. ${ }^{13}$ This seems to a certain degree also to be the case among ostensibly secularized, middle-aged Swedish men who listen to the music of Bob Dylan. ${ }^{14}$

12 I discuss this topic more extensively elsewhere (Häger 2008).

13 There is here a clear connection to Hjalmar Sundén's classic 'role theory', according to which religious experiences are determined by identification with characters from familiar myths (Sundén 1966). 14 Another example of this from the realm of popular music is when electronic dance music, with functional elements of strong community as well as peak experiences through dancing and drugs, use prayers and religious iconography as expressions (Till 2011). 
Bibliography

\section{Botvar, Pål Ketil}

2011 Forever young? Fansens liv med Bob Dylan. - Aasgaard, Reidar, Robert W. Kvalvaag \& Pål Ketil Botvar (eds), Bob Dylan: Mannen, myten og musikken, 219-236. Oslo: Dreyer.

\section{Bourdieu, Pierre}

1986 Kultursociologiska texter. Stockholm: Salamander.

\section{Carr, Revell}

1999 Deadhead tales of the supernatural: A folkloristic analysis - Robert G. Weiner (ed.), Perspectives on the Grateful Dead, 203-12. Westport: Greenwood Press.

\section{Cartwright, Bert}

1985 The Bible in the Lyrics of Bob Dylan. Bury: Wanted Man.

\section{Cavicchi, Daniel}

1998 Tramps Like Us: Music and Meaning among Springsteen Fans. Cary: Oxford University Press.

\section{Gilmour, Michael}

2004 Tangled up in the Bible: Bob Dylan \& Scripture. New York: Continuum.

\section{Häger, Andreas}

2008 Popular Culture and the Sociology of Religion - Lise Kanckos \& Ralf Kauranen (eds.), Social sammanhållning och religion. Festskrift till Susan Sundback, 111-24. Åbo: Åbo Akademi University Press.

2009 Bob Dylan and Religion - Tore Ahlbäck (ed), Postmodern Spirituality, 44-60. Åbo: Donner Institute for Research in Religious and Cultural History.

\section{Heylin, Clinton}

2003 Bob Dylan: Behind the Shades Revisited. New York: Harper Entertainment.

2010 Still on the Road: The Songs of Bob Dylan Vol. 2: 1974-2008. London: Constable.

\section{Jindra, Michael}

2000 'It's about faith in our future': Star Trek fandom as cultural religion - Bruce D. Forbes \& Jeffrey H. Mahan (eds.), Religion and Popular Culture in America, 165-79. Berkeley: University of California Press.

\section{Luckmann, Thomas}

1987 Social Reconstruction of Transcendence - Secularization and Religion: The Persisting Tension: Acts of the XIXth Conference, Tübingen, 25-29 August 1987, 23-31. Tübingen: CISR. 
1990 Shrinking Transcendence, Expanding Religion? - Sociological Analysis $50(2), 127-38$.

\section{Marshall, Scott M.}

2002 Restless Pilgrim: The Spiritual Journey of Bob Dylan. Lake Mary: Relevant Books.

\section{Maoz, Daniel}

2005 Shekhinah as Woman: Kabbalistic References in Dylan's Infidels - Michael Gilmour (ed.), Call Me the Seeker: Listening to Religion in Popular Music, 3-16. New York: Continuum.

\section{Porter, Jennifer E.}

1999 To Boldly Go: Star Trek Convention Attendance as Pilgrimage - Jennifer E. Porter \& Darcee L. McClaren (eds), Star Trek and Sacred Ground: Explorations of Star Trek, Religion and American Culture, 245-70. Albany: State University of New York Press.

Ricks, Christopher

2004 Dylan's Visions of Sin. New York: Ecco.

\section{Riis, Ole \& Linda Woodhead}

2010 A Sociology of Religious Emotion. Oxford: Oxford University Press.

\section{Rouget, Gilbert}

1985 Music and Trance: A Theory of the Relations between Music and Possession. Chicago: The University of Chicago Press.

\section{Schutz, Alfred}

1962 Collected Papers I: The Problem of Social Reality. Haag: Martinus Nijhoff.

\section{Strausbaugh, John}

1995 E-Reflections on the Birth of the Elvis Faith. New York: Blast Books.

\section{Sundén, Hjalmar}

1966 Religionen och rollerna. Ett psykologiskt studium av fromheten. Stockholm: Diakonistyrelsens bokförlag.

\section{Sylvan, Robin}

2002 Traces of the Spirit: The Religious Dimensions of Popular Music. New York: New York University Press.

\section{Till, Rupert}

2011 21st Century Dance Cult: Electronic Dance Music Culture and its Role in Replacing the Traditional Roles of Religion in Western European Popular Youth Culture - Thomas Bossius \& Andreas Häger \& Keith Kahn-Harris (eds), Religion and Popular Music in Europe: New Expressions of Sacred and Secular Identity, 145-61. London: I. B. Tauris. 
Webb, Steven

2006 Dylan Redeemed: From Highway 61 to Saved. New York: Continuum.

\section{Williams, Don}

1985 Bob Dylan: The Man, the Music, the Message. Old Tappan: Fleming H Revell.

\section{Williams, Paul}

1980 What Happened? Glen Ellen: Entwhistle.

2004 Bob Dylan: Performing Artist 1974-1986: The Middle Years. Reading: Omnibus.

Internet Sources

A lily among thorns

<http://www.alilyamongthorns.8m.com> accessed 23 November 2011.

\section{Björner, Olof}

2001 The Best Is Yet To Come. Bob Dylan 2000. <http://www.bjorner. com/2000\%205_9.htm > accessed 2 November 2011.

\section{Church of Bob}

<http://dylanchords.info/churchofbob/> accessed 23 November 2011.

\section{Dylan Devotional}

<http://dylangospel.blogspot.com/> accessed 23 November 2011. 
